\title{
Front Matter: Volume 10246
}

, "Front Matter: Volume 10246," Proc. SPIE 10246, Smart Sensors, Actuators, and MEMS VIII, 1024601 (27 June 2017); doi: 10.1117/12.2282023

SPIE. Event: SPIE Microtechnologies, 2017, Barcelona, Spain 


\title{
PROCEEDINGS OF SPIE
}

\section{Smart Sensors, Actuators, and MEMS VIII}

\author{
Luis Fonseca \\ Mika Prunnila \\ Erwin Peiner \\ Editors \\ 8-10 May 2017 \\ Barcelona, Spain \\ Sponsored by \\ SPIE \\ Cooperating Organisation \\ European Optical Society \\ Published by \\ SPIE
}


The papers in this volume were part of the technical conference cited on the cover and title page. Papers were selected and subject to review by the editors and conference program committee. Some conference presentations may not be available for publication. Additional papers and presentation recordings may be available online in the SPIE Digital Library at SPIEDigitallibrary.org.

The papers reflect the work and thoughts of the authors and are published herein as submitted. The publisher is not responsible for the validity of the information or for any outcomes resulting from reliance thereon.

Please use the following format to cite material from these proceedings:

Author(s), "Title of Paper," in Smart Sensors, Actuators, and MEMS VIII, edited by Luis Fonseca, Mika Prunnila, Enwin Peiner, Proceedings of SPIE Vol. 10246 (SPIE, Bellingham, WA, 2017) Seven-digit Article CID Number.

ISSN: 0277-786X

ISSN: 1996-756X (electronic)

ISBN: 9781510609938

ISBN: 9781510609945 (electronic)

Published by

SPIE

P.O. Box 10, Bellingham, Washington 98227-0010 USA

Telephone +1 3606763290 (Pacific Time) · Fax +1 3606471445

SPIE.org

Copyright @ 2017 , Society of Photo-Optical Instrumentation Engineers.

Copying of material in this book for internal or personal use, or for the internal or personal use of specific clients, beyond the fair use provisions granted by the U.S. Copyright Law is authorized by SPIE subject to payment of copying fees. The Transactional Reporting Service base fee for this volume is $\$ 18.00$ per article (or portion thereof), which should be paid directly to the Copyright Clearance Center (CCC), 222 Rosewood Drive, Danvers, MA 01923. Payment may also be made electronically through CCC Online at copyright.com. Other copying for republication, resale, advertising or promotion, or any form of systematic or multiple reproduction of any material in this book is prohibited except with permission in writing from the publisher. The CCC fee code is 0277-786X/17/\$18.00.

Printed in the United States of America.

Publication of record for individual papers is online in the SPIE Digital Library.

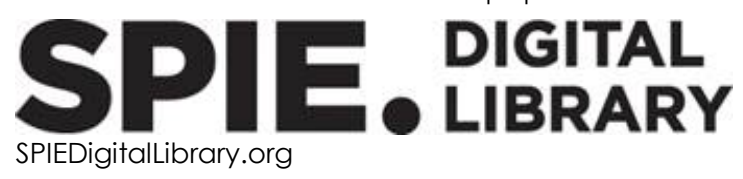

Paper Numbering: Proceedings of SPIE follow an e-First publication model. A unique citation identifier (CID) number is assigned to each article at the time of publication. Utilization of CIDs allows articles to be fully citable as soon as they are published online, and connects the same identifier to all online and print versions of the publication. SPIE uses a seven-digit CID article numbering system structured as follows:

- The first five digits correspond to the SPIE volume number.

- The last two digits indicate publication order within the volume using a Base 36 numbering system employing both numerals and letters. These two-number sets start with 00, 01, 02, 03, 04, 05, $06,07,08,09,0 A, O B \ldots$. OZ, followed by 10-1Z, 20-2Z, etc. The CID Number appears on each page of the manuscript. 


\title{
Contents
}

\author{
vii Authors \\ ix Conference Committees \\ xiii Introduction
}

\section{SESSION 1 MODELING AND SIMULATION I}

1024604 Fluid-structure interaction modelling of the roof tile-shaped modes in piezoelectric plate microresonators [10246-2]

1024606 Optimal design of a microgripper-type actuator based on AIN/Si heterogeneous bimorph [10246-4]

1024607 Topologically optimised flexure hinge based XY stage [10246-5]

\section{SESSION 2 MODELING AND SIMULATION II}

1024608 Modeling high signal-to-noise ratio in a novel silicon MEMS microphone with comb readout [10246-6]

1024609 An FE model of a cellular polypropylene: exploring mechanical properties [10246-8]

10246 OA Efficient fluid transport by a bionically inspired micro-flapper: fluidic investigations using fully coupled finite element simulation [10246-9]

\section{SESSION 3 CHEMICAL AND BIOCHEMICAL SENSORS I}

10246 OB Development of a lab-on-chip electrochemical immunosensor for detection of Polycyclic Aromatic Hydrocarbons (PAH) in environmental water [10246-10]

10246 OC Gravimetric humidity sensor based on ZnO nanorods covered piezoresistive Si microcantilever [10246-11]

10246 OD MEMS-based array for hydrogen sulfide detection employing a phase transition [10246-12]

\section{SESSION 4 CHEMICAL AND BIOCHEMICAL SENSORS II}

10246 OF Inkjet-printed dissolved oxygen and pH sensors on flexible plastic substrates [10246-14]

10246 OG Wax microfluidics light-addressable valve with multiple actuation [10246-15] 
$10246 \mathrm{OH}$ Development of biosensors for non-invasive measurements of heart failure biomarkers in saliva [10246-16]

\section{SESSION 5 PHYSICAL SENSORS I}

10246 Ol MEMS direction finding acoustic sensor [10246-17]

10246 OJ A multi-functional MEMS-SPM for quantitative characterization of nano-objects [10246-18]

10246 OK Asymmetric resonance response analysis of a thermally excited silicon microcantilever for mass-sensitive nanoparticle detection [10246-19]

10246 OL Thermoelectric bolometers based on silicon membranes [10246-20]

\section{SESSION 6 PHYSICAL SENSORS II}

10246 OM Oscillator circuit for monitoring the gas damping effect of piezoelectric microresonators [10246-22]

10246 ON Comparative assessment of PVDF and PVDF-TrFE piezoelectric polymers for flexible actuators applications [10246-23]

1024600 Thin film system with integrated load and temperature sensors for the technical application in deep drawing process [10246-24]

SESSION 7 MATERIALS AND PROCESSES

10246 OP Low cost nanomechanical surfaces stress based sensors fabricated by hybrid materials [10246-25]

10246 OQ Zirconium diboride thin films for use in high temperature sensors and MEMS devices [10246-27]

10246 OR FT-IR analysis of high temperature annealing effects in a-SiC:H thin films [10246-28]

\section{SESSION 8 ENERGY DEVICES I}

10246 OS Micro solid oxide fuel cells: a new generation of micro-power sources for portable applications (Invited Paper) [10246-29]

10246 OT Alkaline fuel cell with nitride membrane [10246-30]

10246 OU Parameter identification from frequency response of MEMS energy harvesters [10246-31]

10246 OV Powering a leadless pacemaker using a PiezoMEMS energy harvester [10246-32] 
10246 OW Designing, modelling and testing of vibration energy harvester with nonlinear stiffness [10246-33]

10246 OX Comparison of methods for static charge energy harvesting on aircraft [10246-34]

10246 OY Improved thermal and electrical design for an all-Si thermoelectric micropower source [10246-35]

$10246 \mathrm{OZ}$ Integrated TiN coated porous silicon supercapacitor with large capacitance per foot print [10246-36]

SESSION 10 INTERFACING AND SYSTEM INTEGRATION

1024610 Programmable differential capacitance-to-voltage converter for MEMS accelerometers [10246-37]

1024611 Robust design of an inkjet-printed capacitive sensor for position tracking of a MOEMSmirror in a Michelson interferometer setup [10246-38]

1024612 Universal and inductorless DC/DC converter for multi-output power supplies in sensor and actuator networks [10246-39]

\section{POSTER SESSION}

1024613 Anti-collision radio-frequency identification system using passive SAW tags [10246-40]

1024614 Mini- and microgenerators applicable in the MEMS technology [10246-41]

1024616 Modeling the microstructure of surface by applying BRDF function [10246-43]

1024617 Actuation control of a PiezoMEMS biomimetic robotic jellyfish [10246-44]

1024618 MEMS-based seed generator applied to a chaotic stream cipher [10246-45]

1024619 Analyses of electromagnetic and piezoelectric systems for efficient vibration energy harvesting [10246-46]

$102461 \mathrm{~A} \quad$ Gold/polypyrrole nanorods for gas sensing application [10246-47]

10246 1B Four segment piezo based micropump [10246-48]

10246 1C Computational model and simulation for the whispering gallery modes inside microoptical cavity [10246-49]

10246 1E Influence of binding material of PZT coating on microresonator's electrical and mechanical properties [10246-51] 
10246 IF Colorimetric sensor for bad odor detection using automated color correction [10246-52]

10246 IG Temperature simulation at ZnO surface processed by laser interference lithography [10246-53]

$10246 \mathrm{1H}$ Innovative metal thermo-compression wafer bonding for microelectronics and MEMS devices [10246-54]

1024611 Characterization of oscillator circuits for monitoring the density-viscosity of liquids by means of piezoelectric MEMS microresonators [10246-55]

10246 IJ Radio link design framework for WSN deployment and performance prediction [10246-56]

$102461 \mathrm{~K}$ User centered integration of Internet of Things devices [10246-57]

$10246 \mathrm{lL}$ Identification of squid species by melting temperature shifts on fluorescence melting curve analysis (FMCA) using single dual-labeled probe [10246-58] 
López de la Torre, M. A., ON

Mandayo, G. G., $1 G$

Manione, Roberto, $1 \mathrm{~K}$

Manz, Johannes, 08

Marcon, P., 14

Márik, Marian, 1A

Martinez-Calderón, M., IG

Mathewson, Alan, OV

Meyer-Kornblum, Eike, 00

Moore, Eric, $\mathrm{OB}$

Morata, A., OY

Moya, A., OF

Olaizola, S. M., $1 G$

Olszewski, Oskar, 0V, 17

O'Murchu, Cian, OV

Orta, Adil Han, 07

Paetsch, Nancy, 00

Palevicius, Arvydas, $1 \mathrm{E}$

Palzer, S., OD

Pannek, C., IF

Parellada-Monreal, L., $1 G$

Park, Eun Kyeong, $1 \mathrm{~L}$

Park, Jihyun, 1L

Park, Sujin, $1 \mathrm{~L}$

Peiner, Erwin, OC, OK

Pérez, A., 18

Pfusterschmied, G., 04, 11

Pilaski, Moritz, OT

Plachta, Kamil, 16

Pozzi, Michele, 09

Prades, J. D., IF

Prunnila, Mika, OL, OZ

Ramon, E., OF

Rebhan, B., $1 \mathrm{H}$

Rodríguez, A., $1 \mathrm{G}$

Romano-Rodríguez, A., IF

Roubal, Z., 14

Royo, G., 10, 18

Rubes, Ondrej, OW, 19

Ruiz, D., 06

Ruiz-Díez, Victor, 04, 0M, 0N, 1 I

Sakalys, Rokas, $1 \mathrm{E}$

Salleras, M., OY

Samur, Evren, 07

Sánchez-Azqueta, C., 10, 18

Sánchez-Rojas, J. L., 04, 06, 0M, 0N, 1 I

Saponara, Sergio, 12, $1 \mathrm{~J}$

Schmid, U., 04, OR, OX, 11

Schmitt, K., IF

Schneider, Michael, OR

Schrag, Gabriele, 08, 0A

Schwarz, P., OM

Seidel, H., OM

Šetka, Milena, 1 A

Sgardelis, Pavlos, 09

Shchepetov, Andrey, OL

Sheorey, Tanuja, 1B

Shepeta, A. P., 13

Shokry, Kirelloss, 1C

Sigmund, $0 ., 06$
Smilek, J., 19

Song, Ha Jeong, $1 \mathrm{~L}$

Sorokin, A. V., 13

Sowade, E., OF

Stewart, David M., OQ

Streklas, Angelos, $\mathrm{OH}$

Sun, Shen-Huei, OT

Swan, William, 01

Szabo, Z., 14

Tarancón, Albert, OS, OY

Tarantik, K., IF

Tijero, Maria, OB

Timofeev, Andrey V., OL

Toledo Serrano, J., 04, OM, 11

Truong, Binh Duc, OU

Vallejos, Stella, 1A

Varpula, Aapo, OL

Vazquez, Patricia, OB

Villa, R., OF, OP

Wachutka, G., OA

Wartmann, Jens, OT

Wasisto, Hutomo Suryo, OC, OK

Wöllenstein, J., OD, $1 \mathrm{~F}$

Wollschläger, Nicole, 0J

Wright, P. K., OX

Wu, Wenze, OK

$\mathrm{XU}$, Jiushuai, $\mathrm{OC}$

Yeatman, E. M., OX

Yeste, J., OP

Yilmaz, Cetin, 07

Zangl, Hubert, 11

Zea, M., OF

Zhang, Xianghui, OJ

Zhou, Hao, OC

Zine, Nadia, $\mathrm{OH}$ 


\title{
Conference Committees
}

\author{
Symposium Chair
}

Ulrich Schmid, Technische Universiteit Wien (Austria)

Symposium Co-chairs

Jacopo lannacci, Findazione Bruno Kessler (Italy)

José Luis Sánchez-Rojas Aldavero, Universidad de Castilla-La Mancha (Spain)

Symposium Local Co-chair

Carles Cané, Centro Nacional de Microelectrónica, CSIC (Spain)

Conference Chair

Luis Fonseca, Centro Nacional de Microelectrónica, CSIC (Spain)

Conference Co-chairs

Mika Prunnila, VTT Technical Research Centre of Finland Ltd. (Finland)

Erwin Peiner, Technische Universität Braunschweig (Germany)

Executive Organising Committee

Rainer Adelung, Christian-Albrechts-Universität zu Kiel (Germany)

Manuel Delgado-Restituto, Instituto de Microelectrónica de Sevilla (Spain)

Jean-Marc Fédéli, CEA-LETI (France)

Luis Fonseca, Centro Nacional de Microelectrónica (Spain)

loanna Giouroudi, DWI an der RWTH Aachen e.V. (Austria)

Erwin Peiner, Technische Univeristät Braunschweig (Germany)

Mika Prunnila, VTT Technical Research Centre of Finland Ltd. (Finland)

Andrei Sarua, University of Bristol (United Kingdom)

Ion M. Tiginyanu, Academy of Sciences of Moldova (Moldova)

Sander van den Driesche, Universität Bremen (Germany)

Laurent Vivien, Institut d'Électronique Fondamentale (France)

Conference Programme Committee

Francisco J. Arregui, Universidad Pública de Navarra (Spain)

Joan Bausells, Centro Nacional de Microelectrónica, CSIC (Spain)

Achim Bittner, Hahn-Schickard (Germany) 
Christian Bolzmacher, Commissariat à l'Énergie Atomique (France) Lionel Buchaillot, IEMN, Université Lille 1 (France)

Viorel Dragoi, EV Group (Austria)

Isabelle Dufour, IMS, Université Bordeaux 1 (France)

Sören Fricke, Robert Bosch GmbH (Germany)

Gerald Gerlach, Technische Universität Dresden (Germany)

Jorge Hernando García, Universidad de Castilla-La Mancha (Spain)

Martin Hoffmann, Technische Universität Ilmenau (Germany)

Carmen Horrillo-Guemes, ITEFI, CSIC (Spain)

Jacopo lannacci, Fondazione Bruno Kessler (Italy)

Enrique Iborra, Universidad Politécnica de Madrid (Spain)

Nathan M. Jackson, Tyndall National Institute (Ireland)

Konrad Kapser, Infineon Technologies AG (Germany)

Robert J. Lad, University of Maine (United States)

Jeong-Bong Lee, The University of Texas at Dallas (United States)

Elie Lefeuvre, Université Paris-Sud 11 (France)

Gemma Garcia Mandayo, CEIT-IK4 (Spain)

Fernando Martinez, IKERLAN, IK4 (Spain)

Dean P. Neikirk, The University of Texas at Austin (United States)

Patrick Pons, Laboratoire d'Analyse et d'Architecture des Systèmes, CNRS (France)

Michele Pozzi, Newcastle University (United Kingdom)

Gabriele Schrag, Technische Universität München (Germany)

Andreas Schütze, Universität des Saarlandes (Germany)

Ashwin Seshia, University of Cambridge (United Kingdom)

Pietro Siciliano, Istituto per la Microelettronica e Microsistemi (Italy) and Consiglio Nazionale delle Ricerche (Italy)

Gabriel Vanko, Slovak Academy of Sciences (Slovakia)

Jürgen Wöllenstein, Fraunhofer-Institut für Physikalische Messtechnik

(Germany)

\section{Session Chairs}

1 Modeling and Simulation I

Michele Pozzi, Newcastle University (United Kingdom)

2 Modeling and Simulation II

Jacopo Iannacci, Fondazione Bruno Kessler (Italy)

3 Chemical and Biochemical Sensors I

Mika Prunnila, VTT Technical Research Centre of Finland Ltd. (Finland)

4 Chemical and Biochemical Sensors II

Jürgen Wöllenstein, Fraunhofer-Institut für Physikalische Messtechnik

(Germany) 
5 Physical Sensors I

Robert J. Lad, The University of Maine (United States)

6 Physical Sensors II

Sören Fricke, Centre Suisse d'Electronique et de Microtechnique SA (Switzerland)

7 Materials and Processes

Erwin Peiner, Technische Universität Braunschweig (Germany)

8 Energy Devices I

Gemma García Mandayo, CEIT-IK4 (Spain)

9 Energy Devices II

Nathan M. Jackson, Tyndall National Institute (Ireland)

10 Interfacing and System Integration

Luis Fonseca, Centro Nacional de Microelectrónica, CSIC (Spain) 
Proc. of SPIE Vol. 10246 1024601-12 Downloaded From: https://www.spiedigitallibrary.org/conference-proceedings-of-spie on 26 Apr 2023
Terms of Use: https://www.spiedigitallibrary.org/terms-of-use 


\section{Introduction}

The SPIE Sensors, Actuators, and MEMS VIII conference took place in Barcelona within the 2017 edition of the SPIE Microtechnologies event.

It gave coverage to a wide breadth of topics with quite a few interlinks among them. Sessions on materials and processing, modeling and simulation, chemical and biochemical sensors, physical sensors, energy devices, and interfacing and systems issues followed for three intense days covering the full food chain of microdevices. Remarkably enough, most of the talks were given by young researchers.

In terms of microtechnologies, silicon technologies, printing technologies, and hybrid technologies were considered making use of both silicon and nonsilicon materials. In terms of applications, the devices considered were thought to contribute to increasing environmental smartness, and to nurturing wearables or loT nodes.

This conference program suited well the overall goal of the SPIE Microtechnologies event, completing the scope of other concurrent conferences: it went a step further into devices than the Nanotechnology VIII conference and complemented the type of devices envisioned in the BioMEMS and Medical Microdevices III conference.

Moreover, the Sensors, Actuators, and MEMS VIII program also complemented very well with the SPIE Microtechnologies plenary talks, which dealt with graphene technologies as an enabling material for bioelectronics, MEMS microphone innovations which is an outstanding market success of a silicon microdevice, and the energy efficiency challenge of smart microsystems which illustrated the system-wise energy challenges of making sensor nodes deployable in loT scenarios in an effective and sustainable way.

Extended abstracts of most of the presented works at Sensors, Actuators and MEMS VIII have found their way into this SPIE proceedings volume, which are now available for further consultation.

\footnotetext{
Luis Fonseca

Mika Prunnila Erwin Peiner
} 
Proc. of SPIE Vol. 10246 1024601-14

Downloaded From: https://www.spiedigitallibrary.org/conference-proceedings-of-spie on 26 Apr 2023 Terms of Use: https://www.spiedigitallibrary.org/terms-of-use 